\title{
Exploring the role of boldness in the Triarchic Psychopathy Model ${ }^{1}$
}

\section{Katarina Sokić ${ }^{2}$ \\ Effectus-College for Law and Finance - The University College, Zagreb, Croatia}

\section{Tajana Ljubin Golub \\ University of Zagreb, Faculty of Teacher Education, Zagreb, Croatia}

\begin{abstract}
According to the Triarchic Psychopathy Model, boldness reflects a syndrome of social dominance, emotional resilience, venturesomeness, and high social efficacy. Based on theoretical assumptions, boldness is an adaptive component of psychopathy and can, therefore, be useful for identifying "successful" expressions of psychopathy. The present study aimed to investigate the relationships between boldness and different prosocial and antisocial criteria (e.g. empathy, impulsivity and aggression) and investigate whether boldness adds incrementally to the established components of psychopathy (i.e. meanness and disinhibition) in predicting these outcomes. Data were collected from the sample of 600 students (308 maleand 292 female) using the Triarchic Psychopathy Measure, the Interpersonal Reactivity Index, the Barratt Impulsiveness Scale-11, and the Reactive-Proactive Aggression Questionnaire. The results have shown that boldness is associated with low personal distress and low non-planning impulsivity. However, boldness was also related to maladaptive tendencies (higher motor impulsivity and higher proactive aggression). The research findings suggest that boldness is related to both adaptive and maladaptive tendencies.
\end{abstract}

Keywords: psychopathy, boldness, empathy, impulsivity, aggression

1 Note: An earlier version of this paper was presented at the European Conference on Personality (ECP 19), Zadar, Croatia, which took place in July 2018. The data presented in this paper was were collected within the framework of the research conducted for the purpose of drawing up the doctoral dissertation by the author Katarina Sokić.

Funding: This research did not receive any specific grant from funding agencies in the public, commercial, or not-for-profit sectors.

Declaration of Conflicting Interests: The authors declare no potential conflicts of interest with respect to the research, authorship, and/or publication of this article. 


\section{Introduction}

Psychopathy is a complex construct characterized by manipulativeness, social dominance and grandiosity, whereas, at the same time,entailing profound affective deficits, such as a lack of empathy/remorse, callousness, fearlessness, shallow emotions, and immunity to stress, but also behavioural deficits such as poor impulse control, aggression, and antisocial behaviour (e.g. Hare \& Neumann, 2008). Non-clinical psychopathy encompasses personality traits of callousness, manipulation, deception, egocentricity, superficial charm, and exploitation, emotional coldness and low empathy, impulsivity, and thrill-seeking. Psychopathy was initially described by Cleckley (1941) in his monograph "The Mask of Sanity" as a disorder that encompassed interpersonal, affective, behavioural, and potentially antisocial components. There are several models of psychopathy (e.g., Hare, 1991/2003, Levenson, Kiehl, \& Fitzpatrick, 1995), and one increasingly popular model is the triarchic psychopathy model (Patrick, Fowles, \& Krueger, 2009). This model tries to reconcile different psychopathy conceptualisations by including three different but intersecting components with psychological and neurobiological correlates, i.e. meanness, disinhibition, and boldness. Both meanness and disinhibition capture emotional-interpersonal deficits, but each captures a different set of deficits. Meanness refers to deficient empathy, lack of affiliative capacity, predatory exploitativeness, empowerment through cruelty or destructiveness, while disinhibition captures the lack of inhibitory control, impulsiveness, difficulties in regulating emotions, hostility and mistrust (Patrick \&Drislane, 2015). Boldness captures social assertiveness, venturesomeness, and stress resistance and has demonstrated stronger associations with adaptive functioning rather than aversive outcomes (e.g., Drislane, Patrick, \& Arsal, 2014; Patrick \& Drislane, 2015).

\subsection{The role of boldness in the triarchic conceptualization of psychopathy}

Theoretically, boldness is based on biologically driven fearlessness, and it is associated with self-confidence, optimism, resilience, tolerance for uncertainty, and social assurance (Patrick et al., 2009). Boldness is found to be associated with socially adaptive characteristics, comprising persuasiveness, stress immunity, conventional value orientation, and well-being, immunity to anxiety/distress, fearlessness, low hostility, high extraversion, emotional stability/low neuroticism, high conscientiousness (e.g., Blagov, Patrick, Oost, Goodman, \& Pugh, 2016; Fanti, Kyranides, Drislane, Colins, \& Andershed, 2016; Ljubin-Golub \& Sokić, 2016; Miller, Lamkin, Maples-Keller, \& Lynam, 2016; Poy, Segarra, Esteller, López, \& Moltó, 2014; Sica et al., 2015). On the other hand, boldness is associated also with maladaptive tendencies, such as 
grandiosity, verbal aggression, specific features of impulsive-antisociality and low agreeableness, narcissism, thrill-seeking, lack of empathy, risk-taking, dishonesty, guiltlessness, lack of altruism, erratic lifestyle and emotional insensitivity (Drislane \& Patrick, 2016; Drislan et al., 2014; Fanti et al., 2016; Marion et al., 2012; Miller, Watts, \& Jones, 2011; Sica et al., 2015; Sellbom \& Phillips, 2013; Stanley, Wygant, \& Sellbom, 2013).

Within thetriarchic psychopathy model, successful psychopathy (which refers to the individuals who are thought to have core personality features of psychopathybut "successfully" function in the society and avoid institutionalization) entails high levels of boldness (probably higher than in unsuccessful psychopathy), low disinhibition and shallow emotions (Lilienfeld, Watts, \& Smith, 2015b). Individuals with higher boldness are resistant to emotional stress and frustration, able to use emotional feedback cues and, therefore, may be more successful and can control and regulate their behaviour.

There is a debate about boldness in literature, and some authors question the role of boldness in the conceptualization of psychopathy because boldness is more associated with adaptive variables (Miller \&Lynam, 2012) and unrelated to either prosocial or harmful criteria (Gatner, Douglas, \& Hart, 2016). By contrast, several other authors (e.g., Lilienfeld et al., 2012) have argued that boldness is a central domain in the historical conceptions of psychopathy, which is correlated with psychopathy-relevant personality traits (e.g., Cleckley, 1941; Lilienfeld et al., 2015a). Boldness showed incremental validity over disinhibition and meanness for the prediction of PCL-R psychopathy, in particular, its interpersonal style (Venables, Hall, \& Patrick, 2014; Wall, Wygant, \& Sellbom, 2014). Additionally, boldness is crucial for differentiating psychopathy from antisocial personality disorder (Venables et al., 2014). However, it seems that further investigations are needed to resolve this issue.

More specifically, it seems that establishing the role of boldness in three central traits associated with psychopathy, i.e. empathy, aggression, and impulsivity, would improve our knowledge about the position of boldness in the nomological network of psychopathy. Insufficient empathy is one of the core characteristics of psychopathy. However, only several authors have examined the association of boldness with empathy. In a study done on a forensic sample, Blair and colleagues (1996) showed that psychopathy was associated with the reduced affective aspects of empathy, but was not associated with the cognitive aspects of empathy. In a community sample, boldness negatively correlated with both cognitive and affective aspects of empathy, except perspective taking (Almeida et al., 2015) for which the association was not significant in bivariate analysis, but showed a positive trend in path analysis. The highest inverse association of boldness and 
aspects of empathy was found with reduced personal distress, which refers to the feelings of personal anxiety and discomfort in intense interpersonal contexts (Almeida et al., 2015). In contrast to that finding, Gatner et. al.(2016) found among undergraduate studentsthat that boldness was positively related and added incrementally to meanness and disinhibition for the Empathy and Emotion Recognition (assessed by Social Emotional Questionnaire). Sellbomand Phillips (2013) found on the female correctional sample that empathy (assessed by the Emotional Empathy scale of Mehrabian \& Epstein, 1972) was not related to boldness, but only to meanness (inversely).

Boldness is usually unrelated to aggression. For example, among undergraduates, there was no relationship of boldness with aggression assessed by the SNAP Negative Temperament and WAI-SF Suppression of aggression scales (Blagov et al., 2016), nor with both STAB physical and social aggression (Gatner et al., 2016), nor with MPQ aggression (Drislane et al., 2014; Hall et al., 2014). However, as suggested by Raine and colleagues (2006), there is a substantial difference between two subtypes of aggression, i.e., proactive and reactive aggression, with each having a different motivation and biological and psychological correlates. Proactive aggression refers to instrumental, proactive, cold-blooded aggression and is accompanied by low levels of autonomic arousal, while reactive aggression is a fear-induced, irritable and hostile defensive response to provocation (Dodge, 1991) and is related to a lack of inhibitory functions and reduced self-control (Raine et al., 1998), executive function deficits (Giancola, Moss, Martin, Kirisci, \& Tarter,1996) and information-processing deficits (Crick \& Dodge, 1996). Proactive aggression is related to psychopathic personality, blunted affect and serious violent offending, while reactive aggression is associated with increased impulsivity, hostility, social anxiety (Raine et al., 2006). To date, there is no published research available that investigates the relationship of boldness (and other triarchic components) with proactive and reactive aggression.

Even more interesting is the relationship of boldness with impulsivity. Impulsivity is considered a multidimensional construct (Patton, Stanford, \& Barratt, 1995; Poythress \& Hall, 2011) and related to (secondary) psychopathy, misbehaviour, and criminal behaviour (Hare \& Neumann, 2008; Patrick et al., 2009; Poythress \& Hall, 2011). In the study of Gatner and colleagues (2016), boldness was unrelated to narrow impulsivity, i.e., acting without thinking (under the motor impulsivity) and weakly negatively associated with the lack of concentration (under the attentional impulsivity) and lack of self-control and intolerance of cognitive complexity (under the non-planning impulsivity), suggesting that boldness is associated with the adaptive features of higher self-control, and tolerance of cognitive complexity. In contrast, also in undergraduates, boldness was shown to have a positive weak relationship with impulsivity as assessed with SNAP (when controlling for meanness and disinhibition) (Blagov et al., 2016). 
To our knowledge, there is little research which examined whether boldness added incrementally to the established components of psychopathy (i.e., meanness and disinhibition) inpredicting diverse external criteria. Further, in the light of the recent boldness debate (Berg, Lilienfeld \& Sellbom,2017; Lilienfeld et al., 2015a; Miller \& Lynam, 2012), it is important to examine the relevance of boldness to psychopathic personality.

\section{Current study and hypotheses}

In order to examine the triarchic conceptualization of psychopathy, and especially the relevance of boldness, we have examined the associations between the triarchic components and psychopathy-relevant personality traits. We are especially interested in testing whether boldness adds incrementally to meanness and disinhibition in predicting empathy, impulsiveness, and aggression. Based on the above discussion, the following hypotheses were set.

Hypothesis 1: Consistent with the notion that boldness indexes emotional resilience, absence of anxiety or neurotic symptoms and capacity to remain calm and focused in pressured or threatening situations (Drislane et al., 2014; Lilienfeld et al., 2015a; Patrick et al., 2009; Patrick \& Drislane, 2015; Patrick, Drislane, \& Strickland., 2012), and based on prior empirical findings (Almeida et al., 2015; Sellbom, Wygant, \& Drislane, 2015; Shou, Sellbom, Xu, Chen, \& Sui, 2017; Stanley et al., 2013), we expect that boldness would be negatively related to personal distress, which measures the feelings of personal anxiety in intense interpersonal contexts.

Hypothesis 2: Based on the triarchic conceptualization of psychopathy that boldness entails the adaptive characteristics which mask the pathology (Patrick, 2006; Patrick \& Drislane, 2015), and empirical evidence of the negative association between boldness and non-planning impulsivity (Gatner et al., 2016), we expect that boldness would be related to low non-planning impulsivity and unrelated to attentional and motor impulsivity.

Hypothesis 3: Based on the theory that boldness entails social poise, social dominance, assertiveness and persuasiveness (Patrick et al., 2009; Patrick\&Drislane, 2015), and in line with the findings that boldness is positively associated with nonphysical victimization and unrelated to physical victimization (Gatner et. al., 2016), we expect that boldness would be related to high proactive aggression and unrelated to reactive aggression.

Hypothesis 4: In the light of the positive associations between boldness and adaptive traits (e.g., Crego \& Widiger, 2014; Miller \& Lynam, 2012; Poy et al., 2014; Sica et al., 2015), we have tested whether boldness added incrementally to the established components of psychopathy (i.e., meanness 
and disinhibition) in predicting empathy, impulsiveness, and aggression. In view of the expectation that boldness would be positively related to proactive aggression and negatively topersonal distress and non-planning impulsivity, we hypothesize that boldness would add incrementally to meanness and disinhibition in predicting these criteria.

\section{Method}

\subsection{Participants and procedure}

The sample originally consisted of 652 students from various faculties and colleges located in Zagreb (70\% financing and law, 21\% engineering and computing, $9 \%$ psychology). The questionnaires of 52 participants were excluded from analyses due to missing data, and the final sample consisted of 600 students (308 men and 290 women), $M_{\text {age }}=21.59, S D=4.41$.

All the students provided informed consent after the nature of the study had been explained to them. The students participated on a voluntary basis during regularly scheduled classes. No identifying information was collected from the participants. It took approximately $40 \mathrm{~min}$ for the participants to complete the surveys. The study was approved by the ethics committee of the Faculty of Arts and Humanities of the University of Zagreb. The sample of undergraduate students was selected since the aim of the study was to assess the continuous score relations of psychopathic traits and criterion variables in a non-criminal setting.

\subsection{Measures}

The Triarchic Psychopathy Measure (TriPM, Patrick, 2010) is a 58-item self-report measure of triarchically conceptualized psychopathy (Patrick et al., 2009), yielding scores on three subscales of Boldness, Meanness, and Disinhibition, as well as a Total Psychopathy score. Items are scored using a 4-point Likert-type scale ranging from 0 (False) to 3 (True). Substantial research has accumulated in support of the construct validity of the TriPM (e.g. Drislane et al., 2014; Sellbom \& Phillips, 2013). The scale was translated and validated in Croatian (Ljubin-Golub \& Sokić, 2016).

The Interpersonal Reactivity Index (IRI; Davis, 1983) is a 28 -item selfreport questionnaire. This scale consists of four separate, seven-item subscales that tap particular facets of empathy. Empathic concern (which measures the tendency to experience feelings of concern and compassion for others), and personal distress subscales assess the affective dimensions of empathy. Fantasy (which measures imaginative transposition of feelings onto fictional others) and perspective taking (which measures the tendency to consider the 
point of view of others) subscales assess its cognitive dimensions. The IRI was translated and used in previous research Croatia (Sokić, 2017).

The Barratt Impulsiveness Scale-11 (BIS-11; Patton, Stanford, \& Barratt, $1995)$ is a 30 -item self-report instrument assessing impulsivity. The BIS-11 captures three domains of impulsivity: attentional impulsivity (reflects poor concentration and thought intrusions), motor impulsivity (reflects acting without thinking), and non-planning impulsivity (reflects a lack of future planning). The BIS-11 was translated and used in previous research (Sokić, 2017).

The Reactive-Proactive Aggression Questionnaire (RPQ; Raine et al., 2006) is a self-report measure that distinguishes the reactive and proactive aggression. The RPQ consists of 23 items: 11 items which measure reactive aggression, and 12 items which measure proactive aggression. Reactive aggression (hostile or impulsive aggression) refers to angry and impulsive responses, which are usually triggered by the provocation or stimuli subjectively interpreted as a provocation. Proactive aggression (instrumental or premeditated aggression) refers to goal-oriented (e.g., bullying, stealing money) predatory aggression which is typically unprovoked. The scale has been validated in Croatia (Ručević \& Duvnjak, 2010).

\subsection{Data Analyses}

To determine the bivariate relationship between psychopathy components and empathy, impulsivity and aggression, zero-order correlations (Pearson Product moment correlation) were calculated. All scales have skewness and kurtosis in the acceptable range of tolerance for normal distribution (between -2 to +2) (George \& Mallery, 2010; Gravetter \& Wallnau, 2014). In order to assess the unique (incremental) variance in different aspects of empathy, impulsiveness and aggression explained by the individual TriPM component, a further set of hierarchical regression analyses were performed. In all models, gender, age, meanness and disinhibition were entered as predictors at Step 1, and boldness was entered in Step 2 of the analysis.

\section{Results}

\subsection{Descriptive analyses}

Descriptive statistics data of all questionnaires, as well as the internal consistency reliability including means and standard deviations, are reported in Table 1. The TriPM, IRI and RPQ scales and subscales demonstrate an adequate range and internal psychometric characteristics in terms of reliability. IRI subscales evidenced somewhat lower than optimal reliabilities. 
All items showed significant corrected item-total correlations within their assigned scales. A one-way ANOVA was used to compare men and women in the mean level of psychopathic traits, empathy, impulsivity and aggression. TriPM Boldness and Meanness and proactive aggression are significantly higher in men, while women scoresare higher on all IRI subscales, with the effect size estimates ranging from small to large.

Table 1

Descriptive data and internal consistency values in men $(N=308)$ and women $(N=291)$.

\begin{tabular}{|c|c|c|c|c|c|c|c|c|c|}
\hline & $\begin{array}{c}\text { Men } \\
M(S D)\end{array}$ & $\begin{array}{l}\text { Women } \\
M(S D)\end{array}$ & $F(1,598)$ & $d$ & $\begin{array}{l}\text { Range } \\
\text { Max. }\end{array}$ & $\begin{array}{l}\text { Range } \\
\text { Actual }\end{array}$ & $\alpha$ & Sk & $\mathrm{Ku}$ \\
\hline \multicolumn{10}{|l|}{ TriPM } \\
\hline Total & $2.23(.28)$ & $2.05(.26)$ & $68.89^{* *}$ & .67 & $1-4$ & $1.40-3.40$ & .86 & 0.56 & 0.62 \\
\hline Boldness & $2.81(.38)$ & $2.65(.44)$ & $24.99^{* *}$ & .39 & $1-4$ & $1.37-3.68$ & .80 & -0.35 & 0.06 \\
\hline Meanness & $2.02(.43)$ & $1.71(.39)$ & $88.74^{* *}$ & .76 & $1-4$ & $1.05-3.37$ & .85 & 0.66 & 0.08 \\
\hline Disinhibition & $1.88(.41)$ & $1.81(.38)$ & 4.83 & .18 & $1-4$ & $1.00-3.50$ & .82 & 0.92 & 1.15 \\
\hline \multicolumn{10}{|l|}{ IRI } \\
\hline Total & $3.14(.46)$ & $3.50(.48)$ & $88.06^{* *}$ & -.76 & $1-5$ & $1.43-4.68$ & .84 & -0.29 & 0.37 \\
\hline $\begin{array}{l}\text { Perspective- } \\
\text { Taking }\end{array}$ & $3.39(.66)$ & $3.59(.65)$ & $13.38^{* *}$ & -.31 & $1-5$ & $1.57-5.00$ & .71 & -0.16 & -0.22 \\
\hline Fantasy & $3.32(.73)$ & $3.67(.82)$ & $29.26^{* *}$ & -.45 & $1-5$ & $1.00-5.00$ & .77 & -0.12 & -0.51 \\
\hline $\begin{array}{l}\text { Empathic } \\
\text { Concern }\end{array}$ & $3.31(.72)$ & $3.82(.69)$ & $76.92^{* *}$ & -.72 & $1-5$ & $1.00-5.00$ & .77 & -0.49 & 0.17 \\
\hline $\begin{array}{l}\text { Personal } \\
\text { Distress }\end{array}$ & $2.52(.65)$ & $2.92(.77)$ & $47.36^{* *}$ & -.56 & $1-5$ & $1.00-4.71$ & .77 & 0.08 & -0.21 \\
\hline \multicolumn{10}{|l|}{ BIS-11 } \\
\hline Total & $2.07(.30)$ & $2.08(.34)$ & .04 & -.03 & $1-4$ & $1.20-3.43$ & .79 & 0.36 & 0.41 \\
\hline $\begin{array}{l}\text { Attentional } \\
\text { Impulsivity }\end{array}$ & $2.21(.43)$ & $2.11(.45)$ & 6.42 & .23 & $1-4$ & $1.00-3.50$ & .61 & 0.18 & -0.16 \\
\hline $\begin{array}{l}\text { Motor } \\
\text { Impulsivity }\end{array}$ & $2.03(.35)$ & $2.04(.41)$ & .00 & -.03 & $1-4$ & $1.18-3.36$ & .62 & 0.50 & 0.27 \\
\hline $\begin{array}{l}\text { Non-Planning } \\
\text { Impulsivity }\end{array}$ & $2.02(.40)$ & $2.10(.40)$ & 5.80 & -.20 & $1-4$ & $1.00-3.45$ & .64 & 0.20 & -0.76 \\
\hline \multicolumn{10}{|l|}{ RPQ } \\
\hline Total & $.64(.29)$ & $.58(.27)$ & 7.84 & .21 & $0-2$ & $.04-1.78$ & .87 & 0.95 & 1.24 \\
\hline $\begin{array}{l}\text { Reactive } \\
\text { Aggression }\end{array}$ & $1.00(.35)$ & $.99(.38)$ & .06 & .03 & $0-2$ & .09-2.00 & .80 & 0.35 & -0.16 \\
\hline $\begin{array}{l}\text { Proactive } \\
\text { Aggression }\end{array}$ & $.33(.30)$ & $.20(.22)$ & $35.10^{* *}$ & .49 & $0-2$ & .00-1.67 & .80 & 0.90 & 1.36 \\
\hline
\end{tabular}

Note: TriPM = Triarchic Psychopathy Measure; IRI= Interpersonal Reactivity Index; BIS11 = Barratt Impulsiveness Scale-11; RPQ = The Reactive-Proactive Aggression Questionnaire. $d=$ Cohen's $d$ index. According to Cohen's (1988) interpretation of effect size, effect sizes around 0.2 are considered small, 0.5 medium, and 0.8 large. $\alpha=$ Cronbach's $\alpha$. Sk- skewness, $\mathrm{Ku}-$ kurtosis. ${ }^{*} p<.01,{ }^{* *} p<.001$. 


\subsection{Correlations among measured variables}

Bivariate correlations among the measured variables can be found in Table 2. Meanness showed moderate correlation with boldness and disinhibition, while boldness and disinhibition were lowly correlated. Intercorrelations among the IRI, BIS-11 and RPQ subscales were none to moderate. These results indicate partial overlap among the observed variables. Boldness correlated mainly with low empathic concern, low personal distress and low non-planning impulsivity. However, it was also related to a lesser degree with low fantasy, low attentional impulsivity, and high proactive aggression. In contrast to boldness, meanness and disinhibition generally shared moderate to large positive correlations with mostly antisocial criteria. Meanness is negatively associated with all IRI subscales and positively with attentional and motor impulsivity, as well as with reactive and proactive aggression. Disinhibition is negatively associated with perspective-taking, and positively with personal distress. Furthermore, disinhibition is positively associated with all the BIS-11 subscales and with both RPQ subscales.

Table 2

Zero-Order Correlations among the measured variables.

\begin{tabular}{|c|c|c|c|c|c|c|c|c|c|c|c|}
\hline & 1 & 2 & 3 & 4 & 5 & 6 & 7 & 8 & 9 & 10 & 11 \\
\hline 1. Boldness & 1 & & & & & & & & & & \\
\hline 2. Meanness & .30 & 1 & & & & & & & & & \\
\hline 3. Disinhibition & -.12 & .40 & 1 & & & & & & & & \\
\hline 4. Perspective- Taking & -.04 & -.47 & -.24 & 1 & & & & & & & \\
\hline 5. Fantasy & -.16 & -.24 & .03 & .27 & 1 & & & & & & \\
\hline 6. Empathic Concern & -.30 & -.69 & -.07 & .41 & .37 & 1 & & & & & \\
\hline 7. Personal Distress & -.64 & -.28 & .17 & .02 & .26 & .40 & 1 & & & & \\
\hline 8. Attentional Impulsivity & -.12 & .24 & .59 & -.18 & .07 & -.02 & .21 & 1 & & & \\
\hline 9. Motor Impulsivity & .06 & .33 & .59 & -.24 & .01 & -.12 & .08 & .51 & 1 & & \\
\hline 10. Non-Planning Impulsivity & -.28 & .08 & .43 & -.22 & $-08^{*}$ & .03 & .27 & .37 & .39 & 1 & \\
\hline 11. Reactive Aggression & -.04 & .28 & .46 & -.26 & $.09^{*}$ & .01 & .24 & .37 & .37 & .24 & 1 \\
\hline 12. Proactive Aggression & -17 & .49 & .56 & -.33 & -.11 & -.19 & .02 & .41 & .39 & .19 & .58 \\
\hline
\end{tabular}

Since we found significant correlations between the TriPM scales, we tested whether multicollinearity was present in each of the models by estimating variance inflation factors (VIF). The VIF value was 1.20 for Boldness, 1.57 for Meanness and 1.29 for Disinhibition, indicating that multicollinearity was not a problem in the regression models. 


\subsection{Incremental value of boldness in predicting empathy, impulsiveness, and aggression}

The results ofhierarchical regression analyses are presented in Table 3.

Table 3

Hierarchical regression investigating the incremental value of boldness in understanding prosocial and antisocial criteria. $N=600$ (308 men, 292 women).

\begin{tabular}{lcllllllll}
\hline & PT & F & EC & PD & AI & MI & NPI & RA & PA \\
\hline Model 1 & & & & & & & & & \\
Gender & -.02 & $.14^{*}$ & $.09^{*}$ & $.18^{* *}$ & -.06 & $.11^{*}$ & $.12^{*}$ & $.10^{*}$ & -.10 \\
Age & -.05 & -.04 & -.05 & -.03 & -.09 & .01 & .02 & -.04 & -.02 \\
Meanness & $-.45^{* *}$ & $-.25^{* *}$ & $-.76^{* *}$ & $-.35^{* *}$ & -.03 & $.16^{* *}$ & -.06 & $.15^{* *}$ & $.28^{* *}$ \\
Disinhibition & -.07 & $.14^{*}$ & $.24^{* *}$ & $.33^{* *}$ & $.60^{* *}$ & $.53^{* *}$ & $.47^{* *}$ & $.41^{* *}$ & $.44^{* *}$ \\
$\mathrm{R}^{2}$ & $.22^{* *}$ & $.10^{* *}$ & $.53^{* *}$ & $.20^{* *}$ & $.36^{* *}$ & $.37^{* *}$ & $.21^{* *}$ & $.24^{* *}$ & $.40^{* *}$ \\
Model 1 & & & & & & & & & \\
Gender & -.01 & $.14^{*}$ & $.09^{*}$ & $.13^{* *}$ & -.06 & $.12^{*}$ & .10 & .10 & -.08 \\
Age & -.05 & -.04 & -.04 & -.02 & -.09 & .00 & .02 & -.03 & -.03 \\
Meanness & $-.49^{* *}$ & $-.23^{* *}$ & $-.75^{* *}$ & $-.13^{* *}$ & -.01 & $.12^{*}$ & .03 & $.16^{* *}$ & $.22^{* *}$ \\
Disinhibition & -.04 & $.13^{*}$ & $.23^{* *}$ & $.17^{* *}$ & $.58^{* *}$ & $.56^{* *}$ & $.40^{* *}$ & $.41^{* *}$ & $.48^{* *}$ \\
Boldness & .01 & -.05 & -.03 & $-.55^{* *}$ & -.06 & $.11^{*}$ & $-.23^{* *}$ & -.02 & $.14^{* *}$ \\
$R^{2}$ & $.23^{* *}$ & $.10^{* *}$ & $.54^{* *}$ & $.45^{* *}$ & $.36^{* *}$ & $.38^{* *}$ & $.25^{* *}$ & $.24^{* *}$ & $.42^{* *}$ \\
$\Delta R^{2}$ & .01 & .00 & .00 & $.25^{* *}$ & .00 & $.01^{*}$ & $.04^{* *}$ & .00 & $.02^{* *}$ \\
\hline
\end{tabular}

Note: The standardised regression coefficients are presented. $R^{2}=$ coefficient of determination. $\Delta R^{2}=$ change for boldness entered in a separate step after controlling for two other TriPM components. $\mathrm{PT}=$ Perspective-Taking; $\mathrm{F}=$ Fantasy; $\mathrm{EC}=$ Empathic Concern; $\mathrm{PD}$ = Personal Distress; AI = Attentional Impulsivity; $\mathrm{MI}=$ Motor Impulsivity; NPI = NonPlanning Impulsivity; RA = Reactive Aggression; PA = Proactive Aggression .

${ }^{*} p<.01,{ }^{* *} p<.001$.

In line with Hypothesis 1, boldness uniquely predicted personal distress $(\beta=-.55, p<.001)$. The negative relationship of boldness with fantasy and empathic concern dropped to non-significance after controlling for meanness and disinhibition, thus suggesting that the negative zero-order association between boldness and these subscales was attributable to the overlap of boldness with meanness and disinhibition. Boldness predicted some aspects of impulsivity, i.e., positively predicted motor impulsivity $(\beta=$ $.11, p=.002)$, and negatively predicted non-planning impulsivity $(\beta=-.23$, $p<.001$ ), thus partially confirming Hypothesis 2. In line with Hypothesis 3 , boldness was associated with proactive aggression $(\beta=.14, p<.001)$, and not with reactive aggression $(\beta=-.02, p=.62)$. Furthermore, the results showed that boldness did add incrementally to meanness and disinhibition in accounting for variance in personal distress $\left(\Delta R^{2}=.25, F[1,594]=\right.$ 98.62, $p<.001)$, motor impulsivity $\left(\Delta R^{2}=.01, F[1,594]=71.40, p<.01\right)$, non- 
planning impulsivity $\left(\Delta R^{2}=.04, F[1,594]=39.43, p<.001\right)$ and proactive aggression $\left(\Delta R^{2}=.02, F[1,594]=85.51, p<.001\right)$. Thus, Hypothesis 4 was partially confirmed.

\section{Discussion}

The aim of this study was to investigate the associations between boldness and both prosocial and antisocial criteria (e.g. empathy, impulsivity, and aggression), and to test whether boldness added incrementally to the established components of psychopathy (i.e. meanness and disinhibition) in predicting these outcomes. The results partially supported the hypotheses and showed that boldness is related to both adaptive and maladaptive tendencies.

Consistent with the hypotheses, and in line with previous studies (Almeida et al., 2015; Sellbom et al., 2015; Stanley et al., 2013), boldness was moderately bivariate associated and was found to be a negative unique predictor in explaining personal distress which measures the feelings of personal anxiety and unease in tense interpersonal settings, i.e. fearfulness (Davis, 1980). Thus, it seems that personal distress shares substantial conceptual overlap with neuroticism. The negative association between boldness and personal distress was also consistent with the studies showing that boldness is related to low anxiety/distress and higher emotional stability (e.g. Fanti et al., 2016; Sica et al., 2015), i.e. lower levels of neuroticism (e.g., Poy et al., 2014; Sica et al., 2015). These results are in line with the theoretical assumptions that boldness is an adaptive component of psychopathy which indexes adaptive traits such as emotional resilience, absence of anxiety or neurotic symptoms (Drislane et al., 2014; Lilienfeld et al., 2015a), and can therefore be useful for identifying "successful" expressions of psychopathy (Hall \& Benning, 2006; Patrick \&Drislane, 2015).

In this study, boldness was negatively associated at a bivariate level with some aspects of emotional empathy (empathic concern) and cognitive empathy (fantasy, i.e., an ability to transpose oneself into the feelings and actions of characters of fiction), but only by virtue of the shared variance with meanness and disinhibition. On the other hand, meanness was strongly and uniquely associated with both low cognitive and low emotional empathy, while, after controlling for two other psychopathy components, disinhibition was positively associated with both emotional empathy (empathic concern) and cognitive empathy (fantasy). Recent research suggests that there are several dissociable components of empathy, i.e., emotional empathy (the capacity to share or affectively resonate with others' emotions), motivational empathy (empathic concern, i.e., the urge to care for another's welfare), and cognitive empathy (affective perspective-taking, 
i.e. the ability to understand the other's thoughts, desires, and feelings) (Decety \& Cowell, 2014). Recent research suggests the presence of separate systems for emotional and cognitive empathy (Shamay-Tsoory, Aharon-Peretz, \& Perry, 2009). Boldness is found to be most consistently associated with low emotional empathy, while the relationship with cognitive empathy is none, negative, or positive (Almeida et al., 2015). In this study, boldness has bivariate associations withlow cognitive empathy as assessed by fantasy, which assesses the tendency to transpose oneself into the feelings and actions of characters of fiction, but was not associated wuth other aspects of cognitive empathy, such as perspective taking, which reflects the tendency to adopt the psychological point of view of others. This is in line with the notion that psychopaths have no deficits in the theory of mind and the ability to understand the feelings and actions of others, but they do not tend to adopt the others' perspective. Also, in keeping with the predictions, boldness is not related to empathic concern which assesses the affective dimensions of empathy.

In accordance with the hypotheses, boldness predicted low nonplanning impulsivity. This is consistent with the triarchic conceptualization of psychopathy which proposes that boldness is a seemingly adaptive component of psychopathy and also in line with a previous study (Gatner et al., 2016). However, contrary to our prediction and previous findings of no relationship with motor impulsivity (Gatner et al., 2016), boldness was found to be positively related to higher motor impulsivity, which reflects narrow impulsivity, i.e. acting without thinking and lack of perseverance. This is consistent with previous studies showing that boldness is related to some form of maladaptive behaviour, e.g. erratic lifestyle (Drislane et al., 2014), and in line with the assumptions of the triarchic model that boldness entails thrill-adventure seeking and tolerance for unfamiliarity and danger (Patrick et al., 2009).

In keeping with the hypotheses, boldness incrementally predicted high proactive aggression and was unrelated with reactive aggression. Proactive aggression was associated with primary psychopathy, and boldness is reflected only to a limited degree in the Interpersonal facet of the PCL-R psychopathy (Patrick et al., 2009; Venables et al., 2014). Our results are in line with the findings that boldness is positively associated with verbal aggression, grandiose manipulative traits, Machiavellian features, including the desire for control/status (Fanti et al., 2016), and with non-physical victimization (Gatner et al., 2016). This finding is consistent with the view that boldness is not purely an adaptive component of psychopathy (Drislane \& Patrick, 2016; Patrick et al., 2009). There is a discussion going on about whether boldness features represent a different pathway to maladaptive behaviour or a protective 
factor with respect to prosocial outcomes (Drislane et al., 2014; Lilienfeld et al., 2015a). The present study showed that boldness adds incrementally to our understanding of some outcomes such as low personal distress, higher motor impulsivity, and higher proactive aggression. With respect to prosocial outcomes, boldness added (negatively) incrementally to meanness and disinhibition in accounting for the variance of non-planning impulsivity, indicating that boldness is related to plannig and purposefull behavior.

\section{Limitations and concluding remarks}

These findings must be considered bearing in mind some limitations. First, the present study used a fairly homogeneous college sample, which limits external validity. Therefore, future studies should replicate the current finding on a forensic sample where psychopathy is the most prevalent. The second limitation considers the reliance on self-report measures which may inflate the associations between the variables. Thirdly, the study is correlational and, therefore, no causal relationships have been confirmed.

Our findings have shown that IRI subscales have somewhat lower than optimal reliabilities ( $\alpha=.79, \alpha=.61, \alpha=.62$, and $\alpha=.64$ for the BIS-11 sum score and the subscales attentional, motor, and non-planning impulsivity). These findings are in line with previous studies on undergraduates (e.g. Gatner et al., 2016; Lange et al., 2017). Reliabilities of the BIS-11 subscales reported in other studies on similar populations were optimal (e.g., Malesza \& Ostaszewski, 2016; Muele, de Zwaan, \& Müller, 2017). Thus, it seems that the reliabilities of the scales vary across the studies, and, therefore, future studies should replicate the results of this research.

The findings of the present research expanded understanding of boldness vis-á-vis its association with diverse external criteria. Results have shown that boldness is related to both adaptive and maladaptive tendencies. Boldness encompasses higher proactive aggression and higher motor impulsivity, which indicates that it is not purely adaptive and a marker of adaptation or successful psychopathy (e.g., Patrick et al., 2009). Consistent with some recent findings (e.g. Gatner et al., 2016), boldness comprises the markers of functional behaviour, such as low reactive aggression and low non-planning impulsivity, as well as a protective factor for experiencing emotional distress. These features protect from the deviant lifestyles and progression of increasing antisocial behaviour, but the question is whether boldness has a synergistic effect with meanness and disinhibition in predicting the maladaptive outcomes. These findings can be useful in detecting and treating the covert antisocial behaviour and in a better understanding of white-collar offenders. 


\section{References}

Almeida, P. R., Seixas, M. J., Ferreira-Santos, F., Vieira, J. B., Paiva, T. O., Moreira, P. S., \& Costa, P. (2015). Empathic, moral and antisocial outcomes associated with distinct components of psychopathy in healthy individuals: a Triarchic model approach. Personality and Individual Differences, 85, 205-211. doi:10.1016/j. paid.2015.05.012

Blair, J., Sellars, C., Strickland, I., Clark, F., Williams, A., Smith, M., \& Jones, L. (1996). Theory of Mind in the psychopath. The Journal of Forensic Psychiatry, 7(1), 1525. doi:10.1080/09585189608409914

Blagov, P. S., Patrick, C. J., Oost, K. M., Goodman, J. A., \& Pugh, A. T. (2016). Triarchic Psychopathy Measure: Validity in relation to normal-range traits, personality pathology, and psychological adjustment. Journal of Personality Disorders, 30(1), 71-81. doi:10.1521/pedi_2015_29_182

Cleckley, H. (1941). The mask of sanity. St. Louis, MO: Mosby.

Crego, C., \& Widiger, T. A. (2014). Psychopathy, DSM-5, and a caution. Personality Disorders: Theory, Research, and Treatment, 5(4), 335-347. doi:10.1037/ per0000078

Crick, N. R., \& Dodge, K. A. (1996). Social information-irocessing mechanisms in reactive and proactive aggression. Child Development, 67(3), 993-1002. doi:10.1111/j.1467-8624.1996.tb01778.x

Davis, M. H. (1980). A multidimensional approach to individual differences in empathy. JSAS Catalog of Selected Documents in Psychology, 10, 85.

Davis, M. H. (1983). Measuring individual differences in empathy: Evidence for a multidimensional approach. Journal of Personality and Social Psychology, 44(1), 113-126. doi:10.1037//0022-3514.44.1.113

Decety, J., \& Cowell, J. M. (2014). The complex relation between morality and empathy. Trends in Cognitive Sciences, 18(7), 337-339. doi:10.1016/j.tics.2014.04.008

Dodge, K.A. (1991). The structure and function of reactive and proactive aggression. In D. Pepler \& K. Rubin (Eds.), The Development and Treatment of Childhood Aggression. (pp. 201-218). Hillsdale: Erlbaum.

Drislane, L. E., \& Patrick, C. J. (2017). Integrating alternative conceptions of psychopathic personality: A latent variable model of Triarchic psychopathy constructs. Journal of Personality Disorders, 31(1), 110-132. doi:10.1521/ pedi_2016_30_240

Drislane, L. E., Patrick, C. J., \& Arsal, G. (2014). Clarifying the content coverage of differing psychopathy inventories through reference to the Triarchic Psychopathy Measure. Psychological Assessment, 26(2), 350-362. doi:10.1037/a0035152

Fanti, K. A., Kyranides, M. N., Drislane, L. E., Colins, O. F., \& Andershed, H. (2016). Validation of the Greek Cypriot translation of the Triarchic Psychopathy Measure. Journal of Personality Assessment, 98(2), 146-154. doi:10.1080/00223891.2 015.1077452

Gao, Y., \& Raine, A. (2010). Successful and unsuccessful psychopaths: A neurobiological model. Behavioral Sciences and the Law, 28, 194-210. doi:10.1002/bsl.924 
Gatner, D. T., Douglas, K. S., \& Hart, S. D. (2016). Examining the incremental and interactive effects of boldness with meanness and disinhibition within the triarchic model of psychopathy. Personality Disorders: Theory, Research, and Treatment, 7(3), 259-268. doi:10.1037/per0000182

Giancola, P. R., Moss, H. B., Martin, C. S., Kirisci, L., \& Tarter, R. E. (1996). Executive cognitive functioning predicts reactive aggression in boys at high risk for substance abuse: A prospective study. Alcoholism: Clinical and Experimental Research, 20(4), 740-744. doi:10.1111/j.1530-0277.1996.tb01680.x

Hall, J. R., Drislane, L. E., Patrick, C. J., Morano, M., Lilienfeld, S. O., \& Poythress, N. G. (2014). Development and validation of Triarchic construct scales from the Psychopathic Personality Inventory. Psychological Assessment, 26(2), 447-461. doi: $10.1037 / \mathrm{a} 0035665$

Hall, J. R., \& Benning, S. D. (2006). The "successful" psychopath: Adaptive and subclinical manifestations of psychopathy in the general population. In C. J. Patrick (Ed.), Handbook of psychopathy. (pp. 459-478). New York: Guilford Press.

Hare, R. D. (2003). The Hare Psychopathy Checklist-Revised (2nd ed.). Toronto: MultiHealth Systems.

Hare, R. D., \& Neumann, C. S. (2008). Psychopathy as a clinical and empirical construct. Annual Review of Clinical Psychology, 4(1), 217-246. doi:10.1146/annurev. clinpsy.3.022806.091452

Levenson, M. R., Kiehl, K. A., \& Fitzpatrick, C. M. (1995). Assessing psychopathic attributes in a noninstitutionalized population. Journal of Personality and Social Psychology, 68(1), 151-158. doi:10.1037//0022-3514.68.1.151

Lilienfeld, S. O., Patrick, C. J., Benning, S. D., Berg, J., Sellbom, M., \& Edens, J. F. (2012). The role of fearless dominance in psychopathy: Confusions, controversies, and clarifications. Personality Disorders: Theory, Research, and Treatment, 3(3), 327-340. doi:10.1037/a0026987

Lilienfeld, S. O., Smith, S. F., Sauvigné, K. C., Patrick, C. J., Drislane, L. E., Latzman, R. D., \& Krueger, R. F. (2016). Is boldness relevant to psychopathic personality? Meta-analytic relations with non-Psychopathy Checklist-based measures of psychopathy. Psychological Assessment, 28(10), 1172-1185. doi:10.1037/ pas0000244

Lilienfeld, S. O., Watts, A. L., \& Smith, S. F. (2015). Successful psychopathy: A scientific status report. Current Directions in Psychological Science, 24(4), 298-303. doi:10.1177/0963721415580297

Ljubin-Golub, T., \& Sokic, K. (2016). The relationships between triarchic psychopathic traits and value orientations in men and women. Psiholoska istrazivanja, 19(2), 185-203. doi:10.5937/psistra1602185l

Marcus, D. K., Fulton, J. J., \& Edens, J. F. (2013). The two-factor model of psychopathic personality: Evidence from the Psychopathic Personality Inventory. Personality Disorders: Theory, Research, and Treatment, 4(1), 67-76. doi:10.1037/ a0025282

Marion, B. E., Sellbom, M., Salekin, R. T., Toomey, J. A., Kucharski, L. T., \& Duncan, S. (2013). An examination of the association between psychopathy and dissimu- 
lation using the MMPI-2-RF validity scales. Law and Human Behavior, 37(4), 219-230. doi:10.1037/lhb0000008

Mehrabian, A., \& Epstein, N. (1972). A measure of emotional empathy. Journal of Personality, 40(4), 525-543. doi:10.1111/j.1467-6494.1972.tb00078.x

Miller, J. D., \& Lynam, D. R. (2012). An examination of the Psychopathic Personality Inventory's nomological network: A meta-analytic review. Personality Disorders: Theory, Research, and Treatment, 3(3), 305-326. doi:10.1037/a0024567

Miller, J. D., Lamkin, J., Maples-Keller, J. L., \& Lynam, D. R. (2016). Viewing the triarchic model of psychopathy through general personality and expert-based lenses. Personality Disorders: Theory, Research, and Treatment, 7(3), 247-258. doi:10.1037/per0000155

Miller, J. D., Watts, A., \& Jones, S. E. (2011). Does psychopathy manifest divergent relations with components of its nomological network depending on gender. Personality and Individual Differences, 50(5), 564-569. doi:10.1016/j.paid.2010.11.028

Patrick, C. J. (2006). The handbook of psychopathy. New York, NY: Guilford Press.

Patrick, C. J. (2010). Operationalizing the triarchic conceptualization of psychopathy: Preliminary description of brief scales for assessment of boldness, meanness, and disinhibition. Tallahassee, Florida: Florida State University. Unpublished test manual. Retrieved from https://www.phenxtoolkit.org/index.php? pageLink=browse.protocoldetails\&id $=121601$

Patrick, C. J., \& Drislane, L. E. (2015). Triarchic model of psychopathy: Origins, operationalizations, and observed linkages with personality and general psychopathology. Journal of Personality, 83(6), 627-643. doi:10.1111/jopy.12119

Patrick, C., Drislane, L. E., \& Strickland, C. (2012). Conceptualizing psychopathy in Triarchic terms: Implications for treatment. International Journal of Forensic Mental Health, 11(4), 253-266. doi:10.1080/14999013.2012.746761

Patrick, C. J., Fowles, D. C., \& Krueger, R. F. (2009). Triarchic conceptualization of psychopathy: Developmental origins of disinhibition, boldness, and meanness. Development and Psychopathology, 21(03), 913. doi:10.1017/ s0954579409000492

Patton, J. H., Stanford, M. S., \& Barratt, E. S. (1995). Factor structure of the barratt impulsiveness scale. Journal of Clinical Psychology, 51(6), 768-774. doi:10.1002/1097-4679(199511)51:6<768::aid-jclp2270510607>3.0.co;2-1

Poy, R., Segarra, P., Esteller, À., López, R., \& Moltó, J. (2014). FFM description of the triarchic conceptualization of psychopathy in men and women. Psychological Assessment, 26(1), 69-76. doi:10.1037/a0034642

Poythress, N. G., \& Hall, J. R. (2011). Psychopathy and impulsivity reconsidered. Aggression and Violent Behavior, 16(2), 120-134. doi:10.1016/j.avb.2011.02.003

Raine, A., Dodge, K., Loeber, R., Gatzke-Kopp, L., Lynam, D., Reynolds, C., . . . Liu, J. (2006). The reactive-proactive aggression questionnaire: differential correlates of reactive and proactive aggression in adolescent boys. Aggressive Behavior, 32(2), 159-171. doi:10.1002/ab.20115

Raine, A., Meloy, J. R., Bihrle, S., Stoddard, J., Lacasse, L., \& Buchsbaum, M. S. (1998). Reduced prefrontal and increased subcortical brain functioning asse- 
ssed using positron emission tomography in predatory and affective murderers. Behavioral Sciences and the Law, 16, 319-332. doi:10.1002/(SICI)10990798(199822)16:3<319::AID-BSL311>3.0.CO;2-G

Sellbom, M., \& Phillips, T. R. (2013). An examination of the triarchic conceptualization of psychopathy in incarcerated and nonincarcerated samples. Journal of Abnormal Psychology, 122(1), 208-214. doi:10.1037/a0029306

Sellbom, M., Wygant, D. B., \& Drislane, L. E. (2015). Elucidating the construct validity of the Psychopathic Personality Inventory Triarchic scales. Journal of Personality Assessment, 97(4), 374-381. doi:10.1080/00223891.2014.962654

Shamay-Tsoory, S.G., Aharon-Peretz, J., \& Perry, D. (2009). Two systems for empathy: a double dissociation between emotional and cognitive empathy in inferior frontal gyrus versus ventromedial prefrontal lesions. Brain, 132(3), 617-627. doi:10.1093/brain/awn279

Shou, Y., Sellbom, M., Xu, J., Chen, T., \& Sui, A. (2017). Elaborating on the construct validity of Triarchic Psychopathy Measure in Chinese clinical and nonclinical samples. Psychological Assessment, 29(9), 1071-1081. doi:10.1037/pas0000398

Sica, C., Drislane, L., Caudek, C., Angrilli, A., Bottesi, G., Cerea, S., \& Ghisi, M. (2015). A test of the construct validity of the Triarchic Psychopathy Measure in an Italian community sample. Personality and Individual Differences, 82, 163 168. doi:10.1016/j.paid.2015.03.015

StanleVenables, N. C., Hall, J. R., \& Patrick, C. J. (2014). Differentiating psychopathy from antisocial personality disorder: a triarchic model perspective. Psychological Medicine, 44(05), 1005-1013. doi:10.1017/s003329171300161x

Wall, T. D., Wygant, D. B., \& Sellbom, M. (2014). Boldness explains a key difference between psychopathy and antisocial personality disorder. Psychiatry, Psychology and Law, 22(1), 94-105. doi:10.1080/13218719.2014.919627 


\title{
Istraživanje uloge smelosti u Trijarhijskom modelu psihopatije
}

\author{
Katarina Sokić
}

EFFECTUS studij financije i pravo, Zagreb, Hrvatska

\section{Tajana Ljubin Golub}

Univerzitet u Zagrebu, Učiteljski fakultet, Zagreb, Hrvatska

U Trijarhijskom modelu psihopatije tvrdi se da smelost odražava sindrom socijalne dominacije, emocionalnerezilijentnosti, avanturizma i visoke socijalne efikasnosti. Na osnovu teorijskih pretpostavki, smelost je adaptivna komponenta psihopatije i stoga može biti korisna za prepoznavanje „uspešnih“ izraza psihopatije. $\mathrm{U}$ ovom radu istražuju se teorijske veze između smelosti i različitih prosocijalnih i antisocijalnih kriterijuma (npr. empatije, impulsivnosti i agresije) i analizira se da li smelost inkrementalno doprinosi ustanovljenim komponentama psihopatije ( $\mathrm{tj}$. zlobi i dezinhibiciji) u predviđanju ovih ishoda. Podaci su prikupljeni na uzorku od 600 studenata (308 muškaraca i 292 žene) koristeći Trijarhijsku meru psihopatije, Indeks interpersonalne reaktivnosti, Baratovu skalu impulsivnosti i Upitnik o reaktivnoj i proaktivnoj agresiji. Rezultati su pokazali da je smelost povezana sa niskomličnom uznemirenošću i niskom impulsivnošću zasnovanom na nedostatku planiranja. Međutim, smelost je takođe povezana sa maladaptivnim karakteristikama (višom motoričkom impulsivnošću i višom proaktivnom agresijom). Nalazi stoga ukazuju na to da je smelost povezana kako sa adaptivnim, tako i sa maladaptivnim karakteristikama.

Ključne reči: psihopatija, smelost, empatija, impulsivnost, agresija 